\title{
Relationship between demographic factors and the performance of teacher education
}

\author{
Sanusi L. Sa'adatu \\ FCT College of Education, Zuba-Abuja, Nigeria
}

\begin{abstract}
The study investigates the relationship between demographic factors on the performance of teacher educators in the FCT. Samples were drawn from teacher educators in the FCT, and a population of 111 staff were used. Data collected were statistically analyzed using single percentages and T-test. Result of the study revealed that over all mean rating on performance of teacher educator toward theirs job is low as indicated by the total grand score of 2.906. Significant differences shows an increase in performance on the basis of age group (46-55 years). Working experience (6 years and above) and educational qualification, indicates that staff with Masters/Phd are more active in carrying out their jobs with a mean of 3.039. It was recommended among others that the government should make efforts to listen to teachers need for training as well as adequate provision for physical infrastructures that will facilitate motivation thereby increasing performance.
\end{abstract}

Keywords: demographic factors; teacher educators; school; Nigeria

\section{INTRODUCTION}

It is believed that no nation can grow beyond the quality of the teachers, a strong-case, now widely recognized, that investing in the education of youth is a critical input for further development which has cluster of more interrelated benefits. In order words education is the bedrock of development of a nation, a tool for securing, a tool which offers solution to challenges related to all areas/aspects of life. This means that teacher educator most be motivated in order to enable them teach and train the further generation.

In a study of teacher motivation, Spuck (1984), indicated that non- material rewards such as social environment, a sense of accomplishment and self-expression are related to job performance. Loitie (1975), on the other hand identified internal satisfaction or psychic rewards as the most powerful reward available to school teachers. It is therefore assumed that to avoid dissatisfaction of teacher educators in the classrooms, a combination of intrinsic rewards, and motivational forces/packages need to be put in place such as being able such as being able to grow personally and professionally. According to Denga (2010), "education is the aggregate of all the continuous and ongoing processes by which a child is enabled to develop the abilities, attitudes, social and occupational competences and other forms of behavior which are a positive value to him/her and the society in which he lives". 
As a key to national development, this teacher educators are the pivot on which any educational development program must depend on for the purpose of this paper, the teacher educators are the teacher found in all educational institutions.

Hertzberg (1959), agreed with the theory of hygiene factors and motivators, which confirmed that satisfaction and dissatisfaction on the job are caused by different factors, which invariably will affect performance.

\section{PURPOSE OF THE STUDY}

* To access the effect of demographic factors on the job performance of teacher educators in the FCT.

* To offer some suggestion on how teacher educators can be properly motivated to increase performance.

\section{SIGNIFICANCE OF THE STUDY}

This study will be of great benefit to the management of FCT ministry of education, employees of labour and the nation as a whole. It is believed that motivation affects performance hence when taken into proper consideration, will result in an increase in performance.

\section{RESEARCH QUESTIONS}

What are the effect of the following on job performance of teacher educator in the FCT, (i). Gender (ii). Age (iii). Work experience and (iv). Educational qualification.

\section{METHODOLOGY}

The study presented the description using simple percentages and T-test statistics.

\section{Research Design}

A survey design involving age, gender, experience and educational qualification as moderating variables.

\section{Sampling Techniques}

The sample consist randomly selected samples of one hundred and eleven (111) teacher educators composing both male and female staff.

\section{Instrumentation}

The questionnaire method was used to guide the perception of each teacher educator. Responses were scored using five point Likert Scales (1932). 


\section{Validity and Reliability}

A pilot study using randomly selected samples from the teacher educators was carried out. The split half method was use to arrive at the co-efficient of reliability of 0.63 was obtained. This can be interpreted as reliable and can be used.

\section{ANALYSIS OF DATA}

Table 1. Characteristics of samples on the basis of bio-data.

\begin{tabular}{|c|c|c|c|}
\hline $\mathrm{S} / \mathrm{N}$ & Categories & Frequency & $\%$ \\
\hline \multirow[t]{4}{*}{1} & Gender: & & \\
\hline & Male & 69 & 62.2 \\
\hline & Female & 41 & 36.9 \\
\hline & Total & & 99.1 \\
\hline \multirow[t]{6}{*}{2} & Age Group: & & \\
\hline & $25-35$ years & 27 & 24.3 \\
\hline & $36-45$ years & 68 & $61: 3$ \\
\hline & $46-55$ years & 15 & 13.5 \\
\hline & No Responses & 1 & .9 \\
\hline & Total & & 100 \\
\hline \multirow[t]{9}{*}{3} & Designation: & & \\
\hline & Graduate Assistant & 43 & 38.7 \\
\hline & Lecturer I & 16 & 14.4 \\
\hline & Lecturer II & 24 & 21.6 \\
\hline & Lecturer III & 16 & 14.4 \\
\hline & Senior Lecturer & 7 & 6.3 \\
\hline & Chief Lecturer & 1 & .9 \\
\hline & No responses & 4 & 3.6 \\
\hline & Total & & 99.1 \\
\hline
\end{tabular}




\begin{tabular}{|c|c|c|c|}
\hline 4 & Experience: & & \\
\hline & 6 years plus & 15 & 13.5 \\
\hline & $3-5$ years & 87 & 78.4 \\
\hline & 2 years plus & 7 & 6.3 \\
\hline & No response & 2 & 1.8 \\
\hline 5 & Total & & $\mathbf{1 0 0}$ \\
\hline & Qualification & 63 & 56.8 \\
\hline & MASTERS/Ph D & 48 & $43.2=100$ \\
\hline
\end{tabular}

In Table 1 under gender, it was observed that out of the 111 respondents 69 (62.2\%) of the total size were male, while $41(36 \%)$ were female staff. With $1(.9 \%)$ no response.

On the basis of age group, $27(24.3 \%)$ are within the age bracket of (25-35) years 67 $(60.4 \%)$ belong to the age group of between $36-45$ years, while $16(14.4 \%)$ belonged to the age group of 46-55. $1(.9 \%)$ however had no response. The distribution of qualification also revealed that the academic staff with HND, BA, B.Ed/Pgde had a total of $63(56.8 \%)$ of the sample belong to staff with degree certificates or the equivalent while $48(43.2 \%)$ of the population had masters and Phd certificates. In terms of working experiences, it is shown that $15(13.5 \%)$ had spent 6 years and above with the college, $87(78.4 \%)$ has spent between 3-5 years while $7(63.3 \%)$ had been with the college for 2 years and above.

The remaining $2(1.8 \%)$ respondents didn't respond. From the statistics gathered, 43 $(38.7 \%)$ of the respondents are graduate assistants $16(14.4 \%)$ lecturer I and $24(21.6 \%)$ belonged to lecturer II cadre. Also on job designation, $16(14.4 \%)$ belonged to lecturer 111,7 $(6.3 \%)$ for the senior lecturers and $1(.9 \%)$ belonged to chief lecturers. However $4(3.6 \%)$ had no response.

\section{DATA ANALYSIS}

Are there differences in the overall mean ratings of performance of the teacher educator on the basis of gender?

Table 2. Mean ratings of performance of the teacher educator on the basis of gender groups.

\begin{tabular}{|c|c|c|c|c|c|c|}
\hline S/N & Gender Groups & $\mathrm{N}$ & $\sum$ & $\bar{X}$ & $\mathrm{Sd}$ & Decision \\
\hline 1 & Male & 69 & 199.1565 & 2.886327 & .5743383 & Low \\
\hline
\end{tabular}




\begin{tabular}{|c|c|c|c|c|c|c|}
\hline 2 & Female & 41 & 120.9153 & 2.94153 & .6200370 & Low \\
\hline & Total & 110 & 320.0718 & 2.909744 & .5897452 & Low \\
\hline
\end{tabular}

The result of Table 2 show means rate of 2.886 for the male academic staff and mean rate of 2.941 for the female staff respondents. The total sum rate of 2.909 proved that both gender groups have low performance.

Are there variations on the overall mean ratings of performance of the teacher educator on the basis of age group categories?

Table 3. Responses of the mean rating of performance of the teacher educator on the basis of age group.

\begin{tabular}{|c|c|c|c|c|c|c|}
\hline S/N & Age Groups & $\mathrm{N}$ & $\sum$ & - & $\mathrm{Sd}$ & Decision \\
\hline 1 & $25-35 \mathrm{yrs}$ & 27 & 71.4624 & 2.646754 & .6645523 & Low \\
\hline 2 & $36-45 \mathrm{yrs}$ & 68 & 201.4236 & 2.962112 & .5570193 & Low \\
\hline 3. & $46-55 \mathrm{yrs}$ & 15 & 46.7897 & 3.119313 & .4809729 & High \\
\hline & Total & 110 & 319.6757 & 2.906143 & .5921540 & Low \\
\hline
\end{tabular}

This table shows that academic staff within the age group of 46-55 years has the highest mean rate of 3.119 as compared to those within the age group of 36-45 years with a mean rate of 2.962 and 2.646 for academic staff within the age group of 25-35 years. The total mean rate of 2.906 indicates that the level of performance is low. Are there variations in the overall ratings of performance of the teacher educator on the basis of job designation categories?

Table 4. Mean ratings of performance on teacher educator on the basis of job designation.

\begin{tabular}{|c|c|c|c|c|c|c|}
\hline Group & Job designation & $\mathrm{N}$ & $\sum$ & $\bar{X}$ & $\mathrm{Sd}$ & Decision \\
\hline 1 & $\begin{array}{c}\text { Lecturer I and } \\
\text { above }\end{array}$ & 24 & 71.9962 & 2.999842 & .4350842 & Low \\
\hline 2 & Lecturer II & 24 & 71.5225 & 2.980116 & .7447220 & Low \\
\hline 3. & Lecturer III & 16 & 44.1718 & 2.760740 & .4055331 & Low \\
\hline 4. & Graduate Assistant & 43 & 121.8342 & 2.833353 & .5414380 & Low \\
\hline & Total & 107 & 309.5250 & 2.892757 & .5560829 & Low \\
\hline
\end{tabular}


Under job designation it was observed that the entire responses indicated low level of performance with an overall mean rate of 2.892. Teacher educators belonging to Lecturer 1 and above had mean rate of 2.999 followed by mean rate of 2.980 for lecturer II category and a mean rate of 2.760 for teacher educators in the lecturer III category. Those belonging to the graduate assistant category had mean rate of 2.833 . The total mean shows low level of performance. Are there variations in the mean ratings of performance in the teacher educator on the basis of working experiences categories?

Table 5. Reponses of mean ratings of performance of the teacher educators on the basis of work experiences.

\begin{tabular}{|l|l|l|l|l|l|l|}
\hline S/N & Working Experiences & $\mathrm{N}$ & $\sum$ & - & Sd & Decision \\
\hline 1 & 6 years plus & 15 & 46.3315 & 3.088766 & .5992724 & High \\
\hline 2 & $3-5$ years & 87 & 251.1346 & 2.886694 & .5802166 & Low \\
\hline 3. & 2 years & 7 & 19.1802 & 2.740033 & .7427077 & Low \\
\hline & Total & 109 & 316.6463 & 2.905012 & .593957 & Low \\
\hline
\end{tabular}

This table shows that teacher educators with 6 years plus in the organization recorded the highest mean rate of 3.088 as against staff who had spent 3-5 years with a mean rate of 2.886. 2.740 for staff with 2 years and above. The total mean of 2.905 was arrived at which also indicate low performance. Are there differences in the mean ratings of performance of the teacher educators on the basis of educational qualification?

Table 6. Reponses of mean ratings of performance of the on the basis of educational qualification.

\begin{tabular}{|c|c|c|c|c|c|c|}
\hline S/N & Educational qualification & $\mathrm{N}$ & $\sum$ & $\bar{X}$ & $\mathrm{Sd}$ & Decision \\
\hline 1 & HND/BA/BAED/PGDE & 63 & 176.4710 & 2.801127 & .5919731 & Low \\
\hline 2 & Master/PhDs & 48 & 145.9190 & 3.039978 & .5644790 & High \\
\hline & Total & 111 & 322.3900 & 2.904414 & .5897374 & Low \\
\hline
\end{tabular}

The variable under these category were divided into 2, the highest belonging to teacher educator with Master/Phd degrees with mean rate of 3.039 and staff with HND/BA, B.Ed/Pgde, had mean rate 2.801. The overall total mean of 2.904 was arrived at. These results agree with the general concept of proper training. Hence, staff with higher degrees are more motivated to work as well as give better performance. 


\section{CONCLUSION}

From the result of this research, it can be concluded that a significant relationship exist between the demographic factors and job performance. The result also showed that teacher educators within 45 years and above, those with higher degrees and staff who had spent many years expressed higher level of satisfaction towards their jobs, leading to a higher level of performance.

\section{Recommendation}

The finding of this study have show that demographic factors have significant effect on job performance while staff performs and succeeds, the performance and success can be attributed to the level of motivational tool provided. All institutions should inculcate better systems of reward for hard work aside from staff promotion, they should also institute an animal staff merit award in respect of good conduct and performance to deserving staff. Adequate physical tools and instructional facilities should be provided in all fields to promote the art of teaching and improving the work-environment. The federal government should also make adequate provision for training and re-training of the teaching force in order to meet the challenges of the era of globalization. Proper educational/supervisory and monitoring bodies should strictly supervise and monitor the establishment and activities of teacher training. This will help to sustain professionalism in the act of teaching.

\section{References}

[1] Hertzberg, Harvard Business Review 68(5) (1987) 109-120.

[2] Loite D. (1975), School teacher, a sociological study. Chicago: University of Chicago press.

[3] Spuck D. W., Educational administration quarterly 10(18) (1984) 31.

[4] Tomáš Hes, Anna Poledňáková, International Letters of Social and Humanistic Sciences 2 (2013) 18-31.

[5] Mohsen Mehrara, Masoumeh zirak, International Letters of Social and Humanistic Sciences 2 (2013) 32-38.

[6] Taiwo Adewale Muritala, Ismail O. Fasanya, International Letters of Social and Humanistic Sciences 2 (2013) 39-50.

[7] Borowski A., International Letters of Social and Humanistic Sciences 3 (2013) 46-53.

[8] Borowski A., International Letters of Social and Humanistic Sciences 3 (2013) 69-74.

[9] Donovan A. McFarlane, International Letters of Social and Humanistic Sciences 4 (2013) 35-44.

[10] Rajesh K. Yadav, Nishant Dabhade, International Letters of Social and Humanistic Sciences 4 (2013) 49-69.

[11] Borowski A., International Letters of Social and Humanistic Sciences 4 (2013) 70-74.

[12] Paul Bukuluki, International Letters of Social and Humanistic Sciences 5 (2013) 27-44.

[13] Mohsen Mehrara, Maysam Musai, International Letters of Social and Humanistic Sciences 5 (2013) 55-62.

[14] Debiprasad Mukherjee, International Letters of Social and Humanistic Sciences 6 (2013) 41-48.

[15] Tomáš Hes, Alena Neradová, Karel Srnec, International Letters of Social and Humanistic Sciences 7 (2013) 55-75. 
[16] Kinga Dziwańska, International Letters of Social and Humanistic Sciences 7 (2013) 96-112.

[17] Borowski A., International Letters of Social and Humanistic Sciences 7 (2013) 113-118.

[18] Mohsen Mehrara, Maysam Musai, International Letters of Social and Humanistic Sciences 8 (2013) 1-7.

[19] Tittenbrun J., International Letters of Social and Humanistic Sciences 11 (2013) 10-34.

[20] Mohsen Mehrara, Hamid Abrishami, Mostafa Boroujli, Mahan Amin, International Letters of Social and Humanistic Sciences 11 (2013) 76-83.

[21] Borowski A., International Letters of Social and Humanistic Sciences 11 (2013) 100-105.

[22] Morteza Amani, Mahmood Goodarzi, Hamze Ahamadian, International Letters of Social and Humanistic Sciences 1 (2014) 7-13.

[23] Seyed Mohammad Marandi, Hossein Pirnajmuddin, International Letters of Social and Humanistic Sciences 1 (2014) 14-27.

[24] Elias Olukorede Wahab, Chioma Joan Ikebudu, International Letters of Social and Humanistic Sciences 1 (2014) 28-42.

[25] Bahram Meihami, Zeinab Varmaghani, Hussein Meihami, International Letters of Social and Humanistic Sciences 1 (2014) 43-5.

[26] Francis Briggs, Elizabeth Desmond, International Letters of Social and Humanistic Sciences 1 (2014) 71-80.

[27] Liverpool E. Onyije, Jacinta A. Opara, International Letters of Social and Humanistic Sciences 1 (2014) 81-87

[28] Sele Sylvester Ebisin, International Letters of Social and Humanistic Sciences 2 (2014) $1-9$.

[29] Tittenbrun J., International Letters of Social and Humanistic Sciences 2 (2014) 20-40.

[30] Borowski A., International Letters of Social and Humanistic Sciences 2 (2014) 110-121.

[31] Pawa Tersoo, International Letters of Social and Humanistic Sciences 3 (2014) 26-36.

[32] Rabi'u Muhammad Ishaq, International Letters of Social and Humanistic Sciences 3 (2014) 37-44.

[33] Adoga James Ada, International Letters of Social and Humanistic Sciences 3 (2014) 45-52.

[34] Bahram Meihami, Hussein Meihami, International Letters of Social and Humanistic Sciences 3 (2014) 80-91.

[35] Kabiru Ibrahim Yankuzo, International Letters of Social and Humanistic Sciences 4 (2014) 1-8.

[36] Onyike Maggaret Odu, International Letters of Social and Humanistic Sciences 4 (2014) 31-39.

[37] Uloma Charity Oguzor, International Letters of Social and Humanistic Sciences 4 (2014) 97-104.

[38] Okezie A. Ihugba, Alex Odii, A. C. Njoku, International Letters of Social and Humanistic Sciences 5 (2014) 21-34.

[39] Okezie A. Ihugba, Bankoli Bankong, N. C. Ebomuche, International Letters of Social and Humanistic Sciences 5 (2014) 92-113.

[40] Borowski A., International Letters of Social and Humanistic Sciences 6 (2013) 86-90. 